\title{
Application of controlled-release nitrogen fertilizer in irrigated common bean crops
}

\author{
Renato Augusto de Oliveira, Wilian Henrique Diniz Buso", Leandro Lopes Gomes, \\ Pedro Henrique Marques Martins, Renato Souza Rodovalho, Henrique Fonseca Elias de Oliveira
}

Goiano Federal Institute, Ceres, Brazil

*Corresponding author, e-mail: wilian.buso@ifgoiano.edu.br

\begin{abstract}
The use of adequate management practices and high nitrogen fertilizer rates have contributed to increase the common bean grain yield, however, the application of nitrogen fertilizer at sowing still requires evaluations for irrigated crops in the Brazilian Cerrado biome region. Thus, the objective of this work was to evaluate the effect of application of different rates of controlledrelease nitrogen fertilizer-dimethylpyrazole phosphate (DMPP) - at sowing and as top-dressing on agronomic performance and leaf area index of irrigated common bean crops grown in the Brazilian Cerrado biome region. A randomized block design in a $4 \times 3$ factorial arrangement with four replications was used. The treatments consisted of four nitrogen rates $(0,60,120$, and 180 $\left.\mathrm{kg} \mathrm{ha}^{-1}\right)$ and three application forms (100\% at sowing, $100 \%$ as top-dressing, and $50 \%$ at sowing $+50 \%$ as top-dressing). Irrigation was managed with class A tanks and two-day intervals. The nitrogen applied at the different stages of the crop did not affect the production components of the common bean plants. The highest grain yields were found with the nitrogen rates of 180 $\mathrm{kg} \mathrm{ha}^{-1}$ in $2015\left(1,756.37 \mathrm{~kg} \mathrm{ha}^{-1}\right)$, and $123.98 \mathrm{~kg} \mathrm{ha}^{-1}$ in $2016\left(1,799.63 \mathrm{~kg} \mathrm{ha}^{-1}\right)$.
\end{abstract}

Keywords: application forms, leaf area index, irrigation, Phaseolus vulgaris, sowing

\section{Introduction}

Common bean (Phaseolus vulgaris) in Brazil is grown divided into three crops: the first in rainy season, the second in the dry season, and the third is an irrigated crop. The irrigated crops of 2017 covered an area of 589 thousand hectares and had grain yield of $1,050 \mathrm{~kg} \mathrm{ha}^{-1}$. Grain yield in the state of Goiás, Brazil, was $2,800 \mathrm{~kg} \mathrm{ha}^{-1}$ in 2016 and $2,900 \mathrm{~kg} \mathrm{ha}^{-1}$ in 2017 in an area of 60,000 hectares (CONAB, 2018).

The cultural, agronomic, and technical characteristics of common bean crops favor its use by small farmers. In addition, common beans have high protein content (22\%); it is a staple food that is consumed with rice by millions of Brazilians (Salgado et al., 2007).

High grain yields of common beans can be achieved with irrigation and intensive use of agricultural inputs; some cultivars reach production of up to $4,000 \mathrm{~kg} \mathrm{ha}^{-1}$ (Farinelli and Lemos, 2010). Low common bean yields are usually due to incorrect management, mainly of fertilization; deficiency of nitrogen directly affects this crop yield. Considering the high cost of nitrogen fertilizers, studies of techniques that can increase their efficiency are necessary (Silva et al., 2006).

According to Moreira et al. (2013), application of nitrogen at sowing supplies the 
requirements of common bean plants cultivated in irrigated systems in the winter and, thus, reduces the need for top-dressing nitrogen fertilization. Soil nitrogen loss through volatilization and leaching decreases in the winter in irrigated systems. The water supplied through irrigation improves the incorporation of $\mathrm{N}$ fertilizer into the soil (Moreira et al., 2013).

Controlled-release nitrogen fertilizer has a protective layer against agents that cause nutrient loss, and do not affect nutrient availability to the plant. In addition, the coating used in this fertilizer allows a gradual release of this nutrient, which is different from that of conventional soluble nitrogen sources (Silva et al., 2012).

Santi et al. (2013) evaluated nitrogen applications in common bean crops and found lower yield in treatments with $100 \%$ of the nitrogen applied at the emergence of the seedlings; the higher yields were found when $100 \%$ of the nitrogen was applied at 28 days after the emergence. This can be attributed to the low nitrogen uptake by the seedlings due to their small roots at this stage, increasing nitrogen losses.

Crop growth analysis consists in evaluating the dry matter assimilation and accumulation, and leaf area of plants, and assessing factors that affect crop development, and final yield (Ghamari and Ahmadvand, 2013), using gravimetric, area, and plant component data. Santos et al. (2015) used growth analysis to evaluate different fertilization rates in common bean crops and found an increase in dry matter and leaf area with increasing fertilization rates, which probably affected positively grain yield.

In this context, the objective of this work was to evaluate the effect of application of different rates of controlled-release nitrogen fertilizer-dimethylpyrazole phosphate (DMPP) at sowing and as top-dressing on agronomic performance and leaf area index of irrigated common bean crops grown in the Brazilian Cerrado biome region.

\section{Material and methods}

The experiment was conducted at the experimental farm of the Federal Institute of Goiás, in Ceres, state of Goiás, Brazil (15²1 '00"S, $49^{\circ} 35^{\prime} 57^{\prime \prime}$ W, and altitude of $564 \mathrm{~m}$ ) under a center pivot irrigation system. The climate of the region is Aw, a hot semi-humid climate with well-defined seasons, according to the Köeppen classification. The soil of the experimental area was classified as Nitossolo (Oxisol) (Embrapa, 2013).

Samples of the $0-20 \mathrm{~cm}$ soil layer were collected for soil fertility evaluation and presented the following results: $482 \mathrm{~g} \mathrm{~kg}^{-1}$ of sand, $40 \mathrm{~g} \mathrm{~kg}^{-1}$ of silt, $478 \mathrm{~g} \mathrm{~kg}^{-1}$ of clay, $\mathrm{pH}$ in $\mathrm{H}_{2} \mathrm{O}$ of $5.62,22 \mathrm{~g} \mathrm{dm}^{-3}$ of organic matter, $3.85 \mathrm{cmol} \mathrm{dm}^{-3}$ of $\mathrm{Ca}, 1.94 \mathrm{cmol} \mathrm{dm}^{-3}$ of $\mathrm{Mg}, 0.00 \mathrm{cmol} \mathrm{dm}^{-3}$ of $\mathrm{Al}$, $3.80 \mathrm{cmol} \mathrm{dm}^{-3}$ of $\mathrm{H}+\mathrm{Al}, 0.56 \mathrm{cmol} \mathrm{dm}^{-3}$ of $\mathrm{K}$, cation exchange capacity of $10.15 \mathrm{cmol} \mathrm{dm}^{-3}, 220.00$ $\mathrm{mg} \mathrm{dm}^{-3}$ of $\mathrm{K}, 50.00 \mathrm{mg} \mathrm{dm}^{-3}$ of $\mathrm{P}$, base saturation of $62.57 \%$, and aluminum saturation of $0.00 \%$.

A randomized block experimental design was used, with a $3 \times 4$ factorial arrangement, consisting of four nitrogen rates $(0,60,120$, and $180 \mathrm{~kg} \mathrm{ha}^{-1}$ ) and three application forms (100\% at sowing, $100 \%$ as top-dressing, and $50 \%$ at sowing $+50 \%$ as top-dressing), with four replications.

Top-dressing fertilization was carried out at the V4 phenological stage (third fully developed trifoliate leaf). The source used for nitrogen fertilization was the product Novatec Solub 45 (Compo, Münster, Germany), which is a granular fertilizer that has nitrogen stabilization technology and is treated with a nitrification inhibitor called dimethylpyrazole phosphate (DMPP).

DMPP allows nitrogen to stabilize as $\mathrm{NH}_{4}^{+}$ for an eight-week period in the soil by inhibiting the conversion of ammonium into nitrate to reduce $\mathrm{N}$ losses. The nitrogen does not pass through the nitrate form and remain as ammonium, reducing $\mathrm{N}$ losses by leaching and increasing the plants' $\mathrm{N}$ absorption efficiency.

Collections for growth analysis, and leaf area index were carried out at six growth stages: $21,29,43,57,71$, and 87 days after emergence (DAE). A randomized block experimental design was used, with a $3 \times 4 \times 6$ factorial arrangement, consisting of four nitrogen rates $(0,60,120$ and $180 \mathrm{~kg} \mathrm{ha}^{-1}$ ), three fertilizer application forms (at sowing, as top-dressing, and $50 \%$ at sowing and $50 \%$ as top-dressing), and six growth stages (21, $29,43,57,71$, and 87 DAE), with four replications.

The plots consisted of six 5-meter 
rows, and the central four meters of the four central rows were used for evaluations, two for determination of production components, and two for growth analysis.

The common bean cultivar BRS-Estilo was sowed on July 21, 2015 and on June 18, 2016, with spacing of $0.50 \mathrm{~m}$ between rows, using 15 seeds per meter to represent 240,000 plants $\mathrm{ha}^{-1}$. The seeds were treated with thiamethoxam (Cruiser, Syngenta, Basel, Switzerland) and fludioxonil + metalaxyl-m (Maxim, Syngenta, Basel, Switzerland), both at the rate of $200 \mathrm{~mL} 100^{-1} \mathrm{~kg}$ of seeds. The emergence of the plants occurred on July 28, 2015 and on June 06, 2016, respectively.

Chemical fertilization at sowing was calculated according to soil chemical characteristics, following the recommendations of Buso et al. (2014), using $16 \mathrm{~kg}$ of nitrogen, 120 $\mathrm{kg}$ of $\mathrm{P}_{2} \mathrm{O}_{5^{\prime}}$ and $64 \mathrm{~kg}$ of $\mathrm{K}_{2} \mathrm{O} \mathrm{ha-1}$ through the formulated fertilizer 4-30-16 (N-P-K).

$\mathrm{N}$ fertilization was performed according to the treatments $1100 \%$ at sowing, $100 \%$ as top-dressing, and $50 \%$ at sowing $+50 \%$ as topdressing). The top-dressing application was performed at 20 DAE.

The herbicides fomesafen (Flex, Syngenta, Basel, Switzerland) at $1 \mathrm{~L} \mathrm{ha}^{-1}$, and fluazifop-p-butyl (Fusilade, Syngenta, Basel, Switzerland) at $1.5 \mathrm{~L} \mathrm{ha}^{-1}$ were applied on August 19, 2015 and June 23, 2016. Insects and diseases were controlled according to technical recommendations for the crop.

A central pivot irrigation system was used, considering daily data of water evaporation from a Class-A tank installed at the meteorological station of the Federal Institute of Goiás, at approximately $600 \mathrm{~m}$ from the experiment area.

The coefficient of the Class-A tank $(\mathrm{Kp})$ is given by the wind speed and air relative humidity of its surrounding area. Irrigation depths were calculated based on the crop coefficients (Kc) at the different stages of plant development, and the evapotranspiration of the Class-A tank. The Kc varied from 0.4 in the first stages to 1.15 in the grain filling stage.

The irrigation was carried out with twoday intervals. The irrigation depths depended on the water evaporation of the Class-A tank during these intervals. A total of $394.56 \mathrm{~mm}$ of water were applied during the 2015 crop cycle, and $427.18 \mathrm{~mm}$ during the 2016 crop cycle. Two rainfalls occurred in 2016, one with $35 \mathrm{~mm}$, and another with $26 \mathrm{~mm}$.

Six plants were randomly collected at harvest and taken to a laboratory to determine their number of pods per plant, number of grains per pod, 1000-grain weight, and plant height (from ground level to apex of the plant). The plants were harvested manually and left to dry at full sun. Then, they were subjected to mechanical threshing, the grains were weighed, and the results were transformed into $\mathrm{kg} \mathrm{ha}^{-1}$.

Two plants were collected at each growth stage, taken to a laboratory to separate their leaves, leaflets, branches, stems, and pods, placed in identified paper bags, and dried in a forced air circulation oven at an average temperature of $60^{\circ} \mathrm{C}$ until constant weight (Silva et al., 2012). The leaves were used to determine leaf area index (LAI) with the aid of the AFSoft ${ }^{\circledR}$ program. The leaf surface was delineated on a table device with a pen and the area was determined by counting the number of squares covered by the delineated surface on the table. The ratio between the area delineated and the table area provided an estimate of the surface area covered by the plants.

Data of production components and agronomic characteristics were subjected to analysis of variance and their means compared by the Tukey's test at 5\%. Regression equations were used to evaluate them as a function of the applied nitrogen rates.

Data of total dry matter (TDM) and leaf area index (LAI) according to the plant collection times, and $\mathrm{N}$ application forms and rates, were analyzed by the Tukey's test at $5 \%$ to compare nitrogen application forms, and by regression analysis to compare the plant collection times. These biometric values were used to obtain the crop growth rate (CGR) and the relative growth rate (RGR) according to Santos et al. (2015).

\section{Results and discussion}

The mean squares were significant for agronomic characteristics and yield of the common bean plants evaluated in 2015 and 2016 (Table 1). There was no significant 
interaction between nitrogen application forms and nitrogen rates in 2015 for any agronomic characteristic evaluated.

According to the regression analysis, the $\mathrm{N}$ rates were significant for plant height, which fitted to a quadratic model; and grain yield, which fitted to a linear model; the other variables did not fit to linear or quadratic models.

Significant interaction in 2016 was found only for plant height (Table 1). The number of grains per pod (NGP) was affected by the $N$ application forms. Plant height fitted to linear models when the nitrogen was applied $50 \%$ at sowing and $50 \%$ as top-dressing (50S50T), and to quadratic models when applying $100 \%$ of the nitrogen at sowing (100S) or $100 \%$ of the nitrogen as top-dressing (100T); grain yield data fitted to a quadratic model.

Table 1. ANOVA with mean squares and significances for plant height (PH), number of pods per plant (NPP), number of grains per pod (NGP), 1000-grain weight (1000GW), and grain yield (GY), of common bean plants, according to sources of variation and regression analysis, forms of nitrogen application (AF), nitrogen rates (NR), and their interaction, in 2015 and 2016.

\begin{tabular}{|c|c|c|c|c|c|}
\hline \multirow{3}{*}{ Variables } & \multicolumn{3}{|c|}{2015} & & \\
\hline & \multicolumn{3}{|c|}{ Mean square } & \multicolumn{2}{|c|}{ Regression } \\
\hline & $\mathrm{AF}$ & NR & $A F \times N R$ & Linear & Quadratic \\
\hline $\mathrm{PH}$ & $110.8158^{\text {ns }}$ & $401.7522 *$ & $92.5447^{n s}$ & ns & $*$ \\
\hline NPP & $66.9608^{*}$ & $4.0389^{n s}$ & $11.4564^{\mathrm{ns}}$ & ns & ns \\
\hline NGP & $1.5676^{*}$ & $0.8864^{\mathrm{ns}}$ & $1.7104^{\mathrm{ns}}$ & $\mathrm{ns}$ & $\mathrm{ns}$ \\
\hline 1000GW & $48.4375^{\text {ns }}$ & $186.1111^{\mathrm{ns}}$ & $613.7153^{\text {ns }}$ & ns & $\mathrm{ns}$ \\
\hline GY & $123361.58^{\mathrm{ns}}$ & $2586636.97^{*}$ & $117475.81^{\mathrm{ns}}$ & $*$ & ns \\
\hline \multicolumn{6}{|c|}{2016} \\
\hline \multirow{2}{*}{ Variables } & \multicolumn{3}{|c|}{ Mean square } & \multicolumn{2}{|c|}{ Regression } \\
\hline & $\mathrm{AF}$ & NR & $A F \times N R$ & Linear & Quadratic \\
\hline $\mathrm{PH}$ & $2347.7115^{*}$ & $1107.7288^{*}$ & $234.6401^{*}$ & $*$ & $*$ \\
\hline NPP & $27.0833 n s$ & 10.4119ns & $27.7711 \mathrm{~ns}$ & ns & ns \\
\hline NGP & $2.1640^{*}$ & $0.4165 n s$ & $0.8269 n s$ & ns & ns \\
\hline 1000GW & $770.0563 \mathrm{~ns}$ & $437.6091 \mathrm{~ns}$ & $1288.1672 \mathrm{~ns}$ & ns & ns \\
\hline GY & $379534.36 \mathrm{~ns}$ & $1441040.92 *$ & $44686.24 n s$ & ns & $*$ \\
\hline
\end{tabular}

According to the agronomic characteristics of the common bean plants in 2015 and 2016 (Table 2), no difference in plant height was found in 2015 due to nitrogen application forms. High plants favor mechanized harvesting, but these plants present high lodging index due to wind than shorter plants. Applications of 1005 may reduce application costs and nitrogen application as top-dressing. Significant interaction between $\mathrm{N}$ application times and rates was found in 2016 (Table 3).

Ramos et al. (2014) evaluated three common bean cultivars of the Rio group (IPR Juriti, IAC-Alvorada, and BRS-Requinte) with $100 \mathrm{~S}$ $\left(100 \mathrm{~kg} \mathrm{ha}^{-1}\right)$, and 100T at $25 \mathrm{DAE}$, and found no difference in plant height, which varied from 66.71 to $70.85 \mathrm{~cm}$, respectively.

The number of pods per plant (NPP) in 2015 (Table 2) was significantly different when comparing the $\mathrm{N}$ application forms; the application of 100 s resulted in higher number of pods per plant (17.69).
The NPP increased with application of 100 S (Table 2) because $\mathrm{N}$ availability at beginning of plant development contributes to increase the plant reproductive nodes. According to Buzzetti et al. (1992), common bean plants require an adequate supply of nitrogen for their growth, and pod and grain formation.

Ramos et al. (2014) found no difference in NPP when applying $\mathrm{N}\left(100 \mathrm{~kg} \mathrm{ha}^{-1}\right)$ using $100 \mathrm{~S}$ (14.51 pods plant ${ }^{-1}$ ) and 100T at 25 DAE (13.13 pods plant ${ }^{-1}$ ).

The NPP was not affected by the nitrogen application forms in 2016 and did not fit to linear or quadratic models in 2015 or 2016 (Table 2). Ramos et al. (2014) found a difference in NPP between treatments without nitrogen application and treatments with $100 \mathrm{~kg} \mathrm{ha}^{-1}$ of nitrogen $(12.20$ and 14.51 plant $^{-1}$, respectively) and reported that nitrogen fertilization contributes to increasing NPP.

The number of grains per pod (NGP) did not fit to regression models as a function of 
nitrogen rates (Table 2). The use of 50S50T resulted in an NGP of 5.05; the application of 1005 resulted in an NGP of 4.66; and the application of 100T resulted in an NGP of 4.43 in 2015 (Table 2). The N application form affected the NGP in 2016 (Table $2)$; the application of 100 s resulted in a higher NGP (6.5).

Thus, when the $N$ is applied at early stages, it increases NGP. However, Ramos et al. (2014) found no difference in NGP for the $N$ rates of $0(3.64)$ and $100(3.60) \mathrm{kg} \mathrm{ha}^{-1}$, for $100 \mathrm{~S}$ and 100T, respectively.

The 1000-grain weight of the plants as a function of nitrogen rates did not fit to linear or quadratic models (Table 2). No difference was found in 1000-grain weight due to $\mathrm{N}$ application forms in 2015 and 2016 (Table 2), which presented $221.87 \mathrm{~g}$ when using $100 \mathrm{~S}, 225.31 \mathrm{~g}$ when using 100T, and $224.06 \mathrm{~g}$ when using 50S50T (2015); for 2016 , these values were $187.73 \mathrm{~g}, 201.26 \mathrm{~g}$, and 197.14 g, respectively. Ramos et al. (2014) found differences in 1000-grain weight when applying $\mathrm{N}$ $\left(100 \mathrm{~kg} \mathrm{ha}^{-1}\right)$ using 100S, and 100T at 25 DAE.

According to the interaction between nitrogen application forms and nitrogen rates for plant height (PH) in 2016 (Table 3), the application of $100 \mathrm{~S}$ provided higher $\mathrm{PH}$, regardless of the nitrogen rates, due to the greater availability of nitrogen at initial development stages, which contributed to a better formation of vegetative structures of the plants.

Table 2. Plant height $(\mathrm{cm})$, number of pods per plant, number of grains per pod, 1000-grain weight, and yield (kg $\mathrm{ha}^{-1}$ ) of common bean plants grown under different $\mathrm{N}$ application forms and rates in 2015 and 2016.

\begin{tabular}{|c|c|c|c|c|c|}
\hline \multicolumn{6}{|c|}{2015} \\
\hline N application & Plant height & Number of pods & Number of grains & 1000-grain & Grain yield \\
\hline form & (cm) & per plant & per pod & weight (g) & $\left(\mathrm{kg} \mathrm{ha}^{-1}\right)$ \\
\hline $100 \mathrm{~S}$ & 110.97 a & $17.69 \mathrm{a}$ & $4.66 \mathrm{a}$ & $221.87 \mathrm{a}$ & $1.623 .00 \mathrm{a}$ \\
\hline $100 T$ & $113.04 \mathrm{a}$ & $13.60 \mathrm{~b}$ & $4.43 a$ & $225.31 \mathrm{a}$ & $1.590 .75 \mathrm{a}$ \\
\hline 50S50T & $107.81 \mathrm{a}$ & $15.49 \mathrm{ab}$ & $5.05 a$ & 224.06 a & $1.756 .37 \mathrm{a}$ \\
\hline CV (\%) & 7.81 & 20.13 & 16.50 & 9.20 & 18.89 \\
\hline \multicolumn{6}{|c|}{2016} \\
\hline $\mathrm{N}$ application & Plant height & Number of pods & Number of grains & 1000-grain & Grain yield \\
\hline form & $(\mathrm{cm})$ & per plant & per pod & weight (g) & $\left(\mathrm{kg} \mathrm{ha}^{-1}\right)$ \\
\hline $100 \mathrm{~S}$ & - & $14.26 \mathrm{a}$ & $6.5 \mathrm{a}$ & $187.73 \mathrm{a}$ & $2.457 .20 a$ \\
\hline $100 \mathrm{~T}$ & - & $14.88 \mathrm{a}$ & $6.1 \mathrm{ab}$ & $201.26 a$ & $2.188 .91 \mathrm{a}$ \\
\hline 50S50T & - & $16.76 \mathrm{a}$ & $5.76 \mathrm{~b}$ & $197.14 a$ & $2.192 .00 \mathrm{a}$ \\
\hline CV (\%) & - & 26.3 & 12.39 & 16.50 & 18.95 \\
\hline
\end{tabular}

Table 3. Interaction between nitrogen application forms and nitrogen rates for plant height (cm) of irrigated common bean plants in 2016.

\begin{tabular}{cccc}
\hline Nitrogen rate & \multicolumn{3}{c}{ Application form } \\
\cline { 2 - 4 }$\left(\mathrm{kg} \mathrm{ha}^{-1}\right)$ & $100 \mathrm{~S}$ & $100 \mathrm{~T}$ & 50 S50T \\
\hline 0 & $92.49 \mathrm{Ba}$ & $72.14 \mathrm{Bb}$ & $86.96 \mathrm{Aa}$ \\
60 & $122.37 \mathrm{Aa}$ & $99.00 \mathrm{Ab}$ & $86.37 \mathrm{Ac}$ \\
120 & $114.71 \mathrm{Aa}$ & $101.77 \mathrm{Ab}$ & $90.00 \mathrm{Ac}$ \\
180 & $118.20 \mathrm{Aa}$ & $101.68 \mathrm{Ab}$ & $92.83 \mathrm{Ab}$ \\
\hline $\mathrm{CV}(\%)$ & & 5.24 & \\
\hline
\end{tabular}

$100 \mathrm{~S}=100 \%$ at sowing; $100 \mathrm{~T}=100 \%$ as top-dressing; $50 \mathrm{~S} 50 \mathrm{~T}=50 \%$ at sowing +50 as top-dressing. $\mathrm{CV}=$ coefficient of variation. Means followed by different uppercase letters in the columns, and lowercase letters in the rows differ by the Tukey's test at $5 \%$ probability.

Regarding the nitrogen rates, the $\mathrm{PH}$ data fitted to a quadratic model, with the highest $\mathrm{PH}$ reached with the rate of $117.97 \mathrm{~kg} \mathrm{ha}^{-1}$ in 2015 (Figure 1A). PH data fitted to a linear model when using 50S50T, with increases in PH with increasing nitrogen rates in 2016; however, $\mathrm{PH}$ fitted to a quadratic model when using $100 \mathrm{~S}$ and 100T
(Figure 1B).

The $\mathrm{N}$ rate that resulted in the highest $\mathrm{PH}$ was $122.22 \mathrm{~kg} \mathrm{ha}^{-1}$ when using $100 \mathrm{~S}$, and 187.5 $\mathrm{kg} \mathrm{ha}^{-1}$ when using 100T (Figure 1B). Soratto et al. (2006) evaluated different sowing times and found higher yields related to greater plants; thus, larger, and more branched plants can produce 

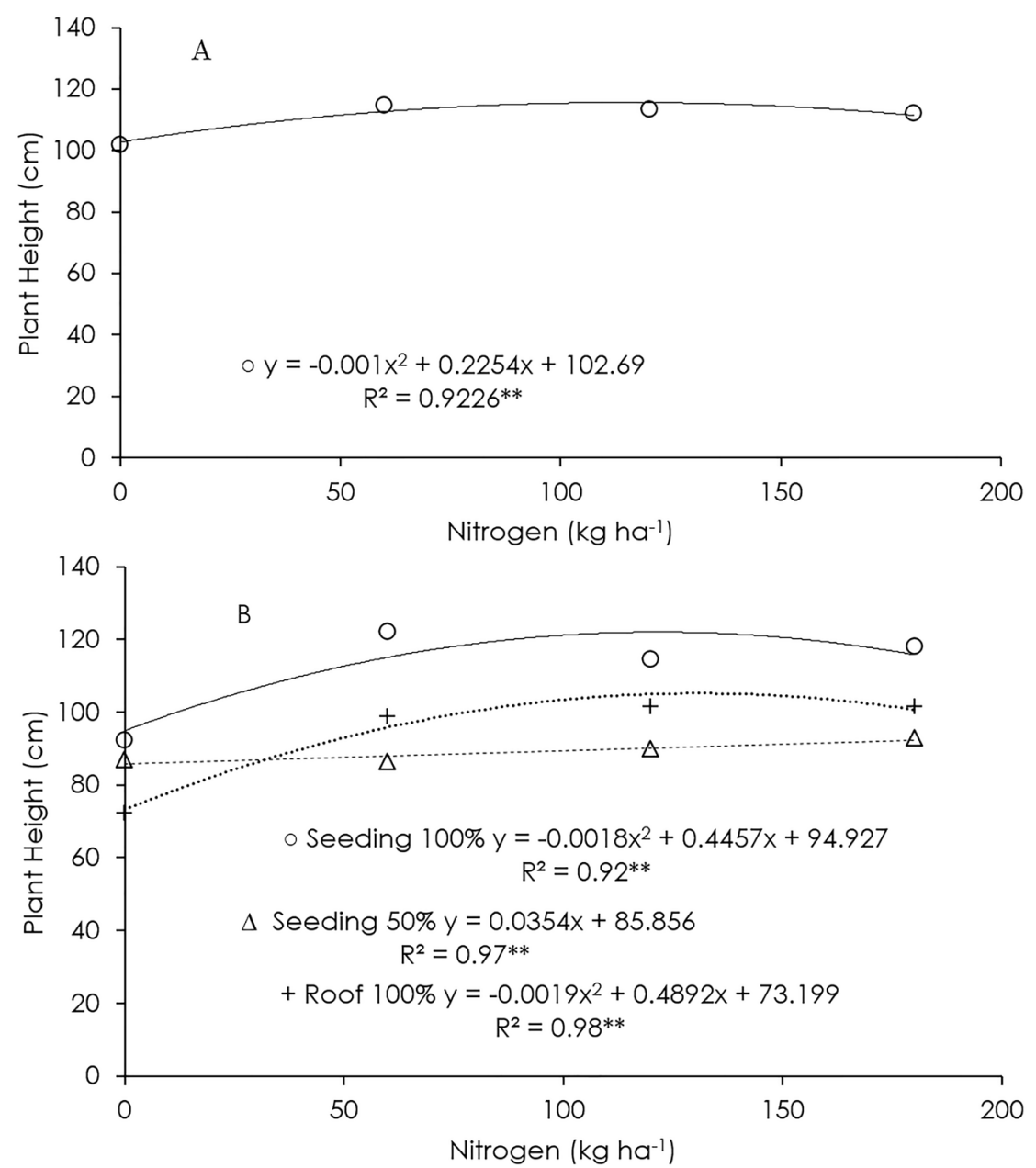

Figure 1. Plant height of common bean (BRS-Estilo cultivar) as a function of nitrogen rates in 2015 (A) and 2016 (B).

greater number of reproductive structures.

Nitrogen application forms had no significant effect on grain yield (GY) (Table 2) in 2015 or 2016. Thus, the use of 100 s may be adopted by producers without GY losses and contribute to reduce operational costs.

Nascente et al. (2016) evaluated N applications $\left(90 \mathrm{~kg} \mathrm{ha}^{-1}\right)$ at three different times (100S, 100T, and 50S50T) and found no difference in GY, with GY of $2,619,2680$, and $2601 \mathrm{~kg} \mathrm{ha}^{-1}$, respectively; thus, nitrogen application time does not affect common bean GY.

GY data fitted to a linear model in 2015 (Figure 2A) $\left(y=1122.7+0.23 x ; R^{2}=0.9179\right)$, with increases in GY with increasing nitrogen rates.

According to Ramos et al. (2014), difference in $\mathrm{GY}$ between $\mathrm{N}$ treatments and control treatments without $N$ fertilization may not be found due to the nitrogen produced by nitrogen-fixing bacteria associated with the common bean roots, or mineralization of organic matter, which can provide sufficient amounts of nitrogen to meet the plant needs. Ramos et al. (2014) found no difference in GY of plants with application of $100 \mathrm{~kg} \mathrm{ha}^{-1}$ of nitrogen, when using 100S or 100T.

According to Campanharo et al. (2010), effects of soil characteristics on nitrogen contents may indicate a higher biological $\mathrm{N}$ fixation when soil conditions are more favorable, resulting in no differences in $\mathrm{GY}$ due to $\mathrm{N}$ rates.

Fiorentin et al. (2011) evaluated nitrogen (urea) rates $\left(0,40,80,120\right.$, and $\left.160 \mathrm{~kg} \mathrm{ha}^{-1}\right)$ applied in the $\mathrm{V} 4$ stage $(50 \%$ of the plants with four fully developed trifoliate leaves) of common bean plants of the Pérola cultivar and found GY of 1,892 to $2,151 \mathrm{~kg} \mathrm{ha}^{-1}$, with no statistical difference, and explained that this similarity may have been caused by residual nitrogen from the previous maize crop.

The GY data as a function of nitrogen rates in 2016 fitted to a quadratic model $(y=$ 

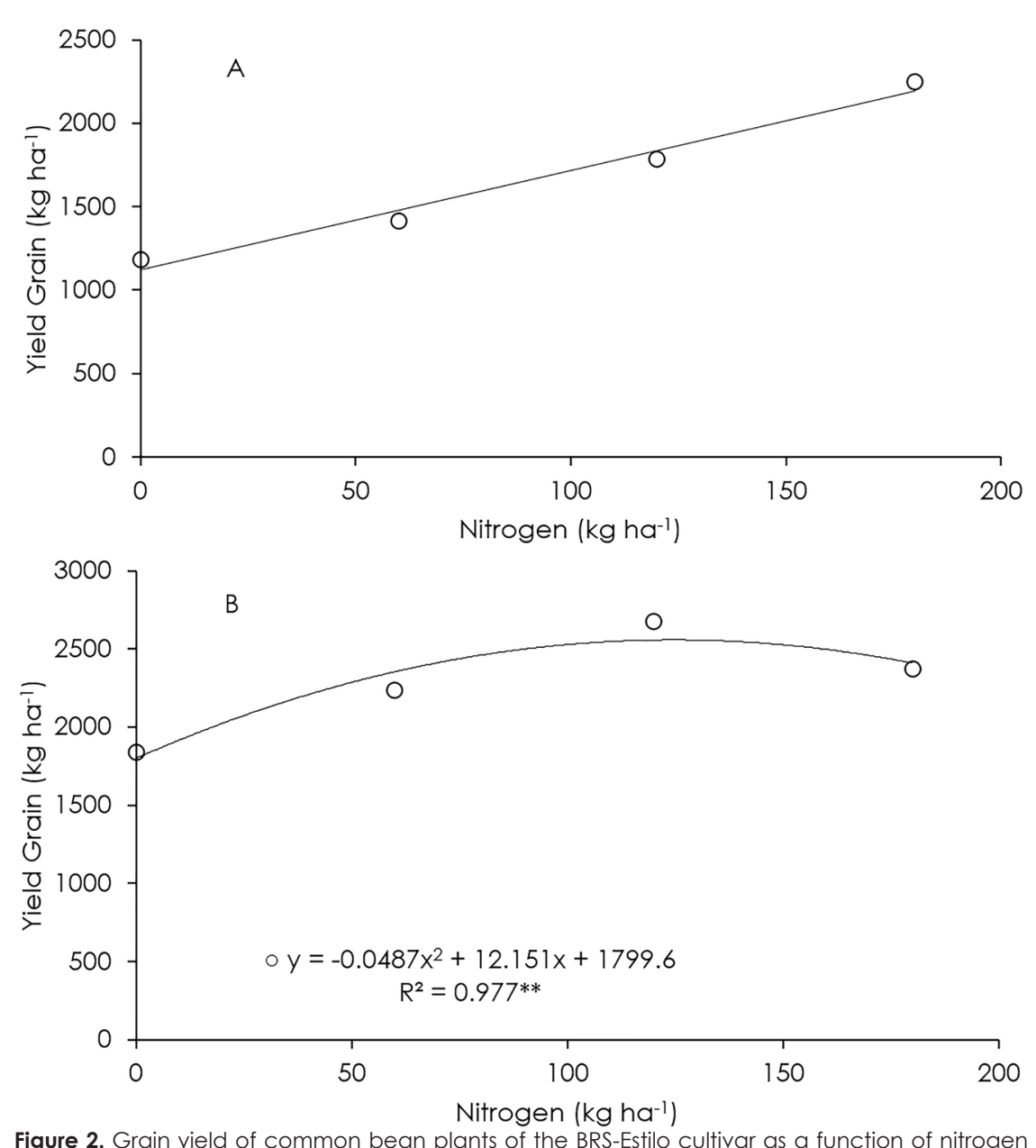

Figure 2. Grain yield of common bean plants of the BRS-Estilo cultivar as a function of nitrogen rates in 2015 (A) and 2016 (B).

$1799.63+12.15 x-0.049 \times 2$ ) (Figure $2 B$ ); the rate that resulted in the highest GY $\left(2,552.81 \mathrm{~kg} \mathrm{ha}^{-1}\right)$ was $123.98 \mathrm{~kg} \mathrm{ha}^{-1}$ of $\mathrm{N}$. Thus, $\mathrm{N}$ rates above those do not increase grain yield, under the conditions of the experiment.

Moreira et al. (2013) evaluated application of nitrogen rates $(0,40,80$, and 120 $\mathrm{kg} \mathrm{ha}^{-1}$ ) at sowing and as top-dressing and found a linear increase in grain yield, regardless of the $\mathrm{N}$ application form, with highest GY $\left(2,404 \mathrm{~kg} \mathrm{ha}^{-1}\right)$ reached with the rate of $120 \mathrm{~kg} \mathrm{ha}^{-1}$.

Therefore, the total $\mathrm{N}$ rate can be applied at sowing in irrigated common bean winter crops in the study region, since its low precipitation rates and the use of irrigation decrease $\mathrm{N}$ losses by leaching and volatilization, making the nutrient available in the soil during the whole crop cycle.

Farinelli and Lemos (2010) evaluated common bean plants of the Pérola cultivar under $N$ (urea) rates $\left(0,40,80,120\right.$, and $\left.160 \mathrm{~kg} \mathrm{ha}^{-1}\right)$ and found a quadratic fit for grain yield, with the highest GY with $185.98 \mathrm{~kg} \mathrm{ha}^{-1}$ of N. Barbosa et al. (2011) evaluated the same cultivar under $\mathrm{N}$ (urea) rates $(0,30,60,90,120$ and $150 \mathrm{~kg} \mathrm{ha}$ ) applied at 20 DAE and found a quadratic fit for GY, with the highest GY with $144 \mathrm{~kg} \mathrm{ha}^{-1}$ of $\mathrm{N}$.

Conventional fertilization and low precipitation rates in winter result in less $\mathrm{N}$ losses due to leaching.

The low GY of 2015 may be related to the different sowing seasons; the plants reached the flowering and grain filling stages in August/September, which presented higher temperatures (Table 2).

Smiderle et al. (2014) evaluated common bean plants of the Pérola cultivar with $\mathrm{N}$ fertilization (40 $\mathrm{kg} \mathrm{ha}^{-1}$ ) at 15 DAE and reported that, despite controlling the water depth, the competition of plants within the plots may affect the results due to environmental factors-temperature, relative air humidity, and photoperiod.

The total dry matter (TDM) and the leaf area index (LAI) in 2016 were not affected by the $\mathrm{N}$ application forms or rates. 
TDM data fitted to a quadratic model (Table 4), with an increase from $0.01 \mathrm{~kg} \mathrm{~m}^{-2}$ at 21 DAE to $0.06 \mathrm{~kg} \mathrm{~m}^{-2}$ at 57 DAE. The TDM reduced from $57 \mathrm{DAE}$ to $87 \mathrm{DAE}$, which presented a mean of $0.04 \mathrm{~kg} \mathrm{~m}^{-2}$.

Martins et al. (2017) found similar results when evaluating the growth of common bean plants of the BRS-Estilo cultivar under different $\mathrm{N}$ application forms, and rates $(0,60,120$ and 180 $\mathrm{kg} \mathrm{ha}^{-1}$ ) in 2015, and explained these results by the growth stages of the plants and their senescence process.

LAl data (square meter of leaves per square meter of the plant) also fitted to a quadratic model (Table 4); the highest estimated LAI was 81.88 at $58 \mathrm{DAE}$, with increases from 13.31 at $21 \mathrm{DAE}$ to 88.31 at $57 \mathrm{DAE}$, with a subsequent reduction to 38.29 .

The highest LAI was found at 43 to 57 DAE, at the grain filling period. Santos et al. (2015) found similar results when analyzing the growth of common bean plants under five sowing densities $\left(8,10,12,14\right.$, and 18 plants $\left.\mathrm{m}^{-1}\right)$; the increase in LAI was due to increases in the number of leaves and expansion of the leaf blade; and the decrease in LAI was due to increases in other tissues and structures, auto shading, senescence, grain filling, and leaf falling.

Table 4. Regression equations for total dry matter (TDM) and leaf area index (LAI) of common bean plants grown under $\mathrm{N}$ fertilization with different application forms and rates.

\begin{tabular}{|c|c|c|}
\hline Production factor & Equation & $\mathrm{R}^{2}$ (decimal) \\
\hline $\begin{array}{l}\text { TDM } \\
\left(\mathrm{kg} \mathrm{m}^{-2}\right)\end{array}$ & TDM $=-0.0585+0.0037 \times D A E-3 \times 10^{-5} \times D_{A} E^{2}$ & $0.8207^{*}$ \\
\hline $\begin{array}{l}\text { LAI } \\
\text { ( } \mathrm{m}^{2} \text { of leaves per } \mathrm{m}^{2} \text { of plant) }\end{array}$ & $\mathrm{LAI}=-97.1610+6.1958 \times \mathrm{DAE}-0.0536 \times \mathrm{DAE}^{2}$ & $0.9641^{*}$ \\
\hline
\end{tabular}

The curves of crop growth rate (CGR) of the common bean plants of the cultivar BRSEstilo as a function of $\mathrm{N}$ application forms (Figure 3A) and rates (Figure 3B) indicate a relationship between CGR with TDM and LAI. The highest of CGR were found at 30 to 40 DAE due to the intense growth of reproductive structures in this period, with subsequent reductions to negative values due to the reduction in LAI.
According to Santos et al. (2015), the CGR of common bean plants of the Pérola, and IAC-Alvorada cultivars subjected to $\mathrm{N}, \mathrm{P}$, and $K$ fertilization rates $10 \%, 50 \%$, and $100 \%$ of the recommended rate) increased up to 55 DAE.

These different results are related to differences in the cycles and growth habits of the common bean cultivars.

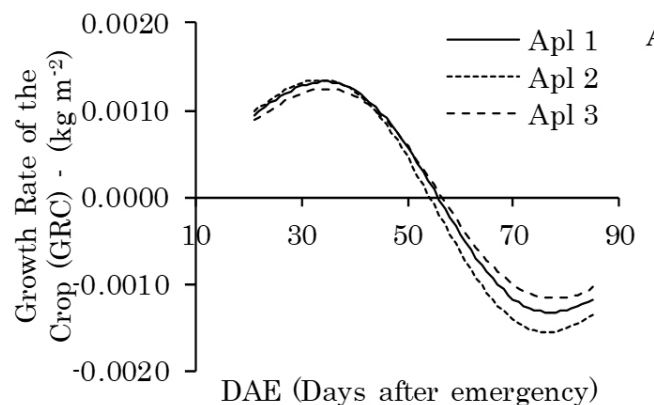

DAE (Days after emergency)

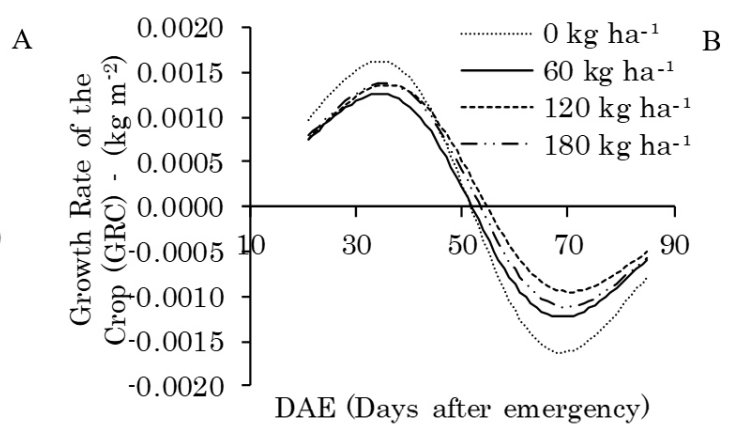

DAE (Days after emergency)

Figure 3. Crop growth rate of common bean plants of the BRS-Estilo cultivar subjected to different nitrogen application forms ( $100 \%$ at sowing - $100 \mathrm{~S}, 100 \%$ as top-dressing - $100 \mathrm{~T}$, and $50 \%$ at sowing $+50 \%$ as top-dressing - 50S50T) (A) and nitrogen rates $\left(0,60,120\right.$, and $\left.180 \mathrm{~kg} \mathrm{ha}^{-1}\right)(B)$ as a function of days after emergence (DAE).

The relative growth rate (RGR) is based on the TDM produced by the crop. The RGR of all treatments fitted to linear models, with decreasing in RGR over the cycle for the different
$\mathrm{N}$ application forms (Figure 4A) and rates (Figure $4 \mathrm{~B})$.

This result agrees with that of Ghamari and Ahmadvand (2013), who evaluated 
common bean crops under $45 \mathrm{~kg} \mathrm{ha}^{-1}$ of $\mathrm{N}$, and weed infestation. They found reduction of RGR over the cycle, which is caused by auto shading, production of non-photosynthetic tissues (pods and grains) that drain photoassimilates, and occurrence of greater respiratory activity (Silva et al., 2012).
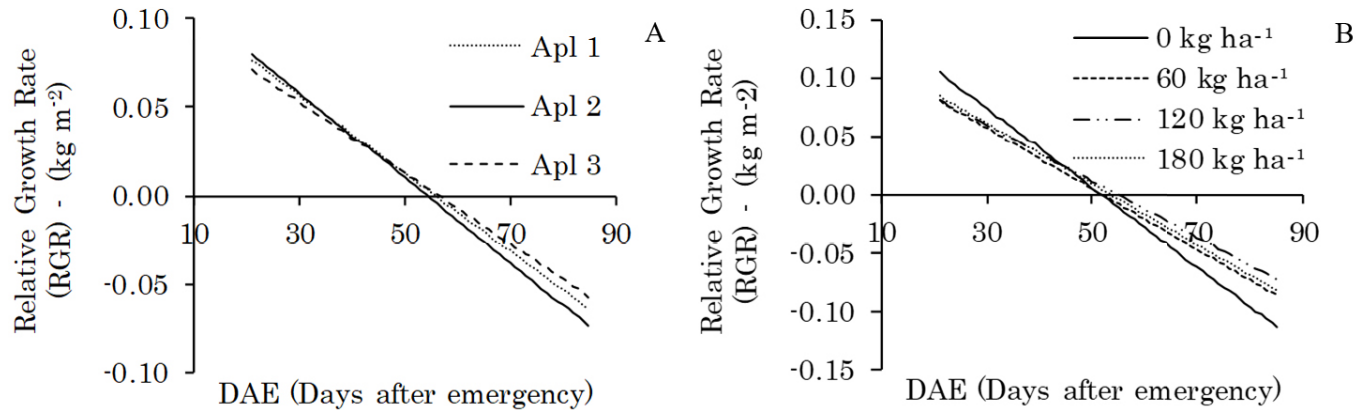

Figure 4. Relative growth rate of common bean plants of the BRS-Estilo cultivar subjected to different nitrogen application forms (100\% at sowing - $100 \mathrm{~S}, 100 \%$ as top-dressing - 100T, and $50 \%$ at sowing $+50 \%$ as top-dressing - 50S50T) (A) and nitrogen rates $\left(0,60,120\right.$, and $\left.180 \mathrm{~kg} \mathrm{ha}^{-1}\right)$ (B) as a function of days after emergence (DAE).

\section{Conclusions}

The effect of nitrogen fertilization on production components of common bean crops depends on their development stage.

The application of a nitrogen rate of $123.98 \mathrm{~kg} \mathrm{ha}^{-1}$ on common bean plants grown in Nitossolo (Oxisol) increases grain yield.

The application of $100 \%$ of the nitrogen rate at sowing does not affect production components of common bean plants when using controlled-release nitrogen fertilizer, which reduces mechanized operations.

The highest total dry matter was found at 57 days after emergence, and the highest leaf area index was found between flowering and pod formation, regardless of the treatments used.

Nitrogen application forms and rates do not affect the crop growth rate and relative growth rate of common bean under the conditions of this study.

\section{Acknowledgements}

The authors thank the agronomists Julio Canhete, and Fernanda Cabral Pontes Santaniel of the company Compo do Brasil for the donation of the nitrogen fertilizer; and the Federal Institute of Goiano Campus Ceres, for financial support.

\section{References}

Barbosa, R.M., Costa, D.S., Homem, B.F.M., Sá M.E. 2011 . Nitrogênio na produção e qualidade de sementes de feijão. Pesquisa Agropecuária Tropical 41: 470-474.
Bastos, E.A., Rodrigues, B.H.N., Andrade Júnior, A.S., Cardoso, M.J. 2002. Parâmetros de crescimento do feijão caupi sob diferentes regimes hídricos. Engenharia Agrícola 22: 43-50.

Buso, W.H.D., Silva, L.B., Rios, A.D.F. 2014. Componentes produtivos de feijão em duas épocas de plantio na região central de Goiás. Revista Agrarian 7: 205-210.

Campanharo, M., Lira Junior, M.A., Nascimento, C.W.A., Stamford, N.P., Freire, F.J., Costa, J.V.T. 2010. Acidez do solo na fixação biológica de nitrogênio em feijoeiro comum. Revista Brasileira de Ciências Agrarias 5: 285-290. DOI: 10.5239/ agraria. v5i3a436

CONAB. Companhia Nacional de Abastecimento. Relatório de Safra. Disponível em: https://www.conab.gov.br/info-agro/safras/ graos. Acesso em 12/12/2018.

EMBRAPA - Empresa Brasileira de Pesquisa Agropecuária. 2013. Sistema brasileiro de classificação de solos. $3^{a}$ ed., EMBRAPA. Brasília, Brasil. 353 p.

Farinelli, R., Lemos, L.B. 2010. Produtividade, eficiência agronômica, características nutricionais e tecnológicas do feijão adubado com nitrogênio em plantio direto e convencional. Bragantia 69: 165-172.

Fiorentin, C.F., Lemos, L.B., Jardim, C.A., Fornasieri Filho, D. 2011. Formação e manutenção de palhada de gramíneas concomitante à influência da adubação nitrogenada em cobertura no feijoeiro irrigado em sistema de semeadura direta. Bragantia 70: 917-924.

Ghamari, H., Ahmadvandgrowth, G. 2013. Analysis of Dry Bean (Phaseolus vulgaris L.) in Different Weed Interference Situations. Notice 
Science Biology 5: 394-399.

Martins, P.H.M., Oliveira, R.A.A., Buso, W.H.D., Rodovalho, R.S. 2017. Análise de crescimento do feijoeiro a diferentes manejos de adubação nitrogenada na região do cerrado. Revista Agrotecnologia 8: 63-70.

Moreira, G.B.L., Pegoraro, R.F., Vieira, N.M.B., Borges, L., Kondo, M.K. 2013. Desempenho agronômico do feijoeiro com doses de nitrogênio em semeadura e cobertura. Revista Brasileira de Engenharia Agrícola e Ambiental 17: 818-823.

Nascente, A.S., Heinemann, A.B., Alves, L.C., Rosa, P.H., Naves, L.F.V., Garcia, A.C.F. 2016. Development of super early genotypes for the dry bean (Phaseolus vulgaris) as affected by nitrogen management. Australian Journal of Crop Science 10: 1118-1126.

Ramos, D.P., Sousa, S.A., Oliveira, T.C., Gonçalves, G.M.O., Passos, N.G.; Fidelis, R.R. 2014. Adubação nitrogenada no feijoeiro comum irrigado em diferentes épocas, com e sem parcelamento das doses. Biotemas 27: 9-214.

Salgado, T.P., Salles, M.S., Martins, J.V.F., Alves, P. 2007. Interferência das plantas daninhas no feijoeiro carioca. Planta daninha 25: 443-448.

Santi, A.L., Basso, C.J., Lamego, F.P., Flora, L.P.D., Amado, T.J.C., Cherubin. M.R. 2013. Épocas e parcelamentos da adubação nitrogenada aplicada em cobertura na cultura do feijoeiro, grupo comercial preto e carioca, em semeadura direta. Ciência Rural 43: 816-822.

Santos, L.A., Soratto, R.P., Fernandes, A.M., Gonsales, J.R. 2015. Crescimento, índices fisiológicos e produtividade de cultivares de feijoeiro sob diferentes níveis de adubação. Revista Ceres 62: 107-116.

Silva, A.A., Silva, T.S., Vasconcelos, A.C.P., Lana, R.M.Q. 2012. Aplicação de diferentes fontes de ureia de liberação gradual na cultura do milho. Biosciense Journal 28: 104-111.

Silva, R.R., Scariotto, S., Malagi, G., Marchese, J.A. 2012. Análise de crescimento em feijoeiro cultivado sob diferentes densidades de semeadura. Scientia agraria 13: 41-51.

Silva, T.R.B., Lemos, L.B., Tavares, C.A. 2006. Produtividade e característica tecnológica de grãos em feijoeiro adubado com nitrogênio e molibdênio. Pesquisa agropecuária brasileira 41: 739-745.

Smiderle, E.C., Botelho, F.B.S., Guilherme, S.R., Arantes, S.A.C.M., Botelh, R.T.C., Arantes, K.R. 2014. Tamanho de parcelas experimentais para a seleção de genótipos na cultura do feijoeiro. Comunicata Scientiae 5: 51-58.
Soratto, R.P., Crusciol, C.A.C., Silva, L.M., Lemos, L.B. 2006. Parcelamento da adubação nitrogenada de cobertura no feijoeiro em sistema de plantio direto. Científica 34: 223-228 